\title{
FORMAL AND NON-FORMAL EDUCATION AND TRAINING AS AN INSTRUMENT FOSTERING INNOVATION AND COMPETITIVENESS IN EU MEMBER COUNTRIES
}

\section{- Sabina Denkowska, Kamil Fijorek, Grazyna Wegrzyn}

\begin{abstract}
An important role in economic development and competitiveness is played by human capital, that is believed to lead to the growth of innovation. The innovative activities of companies, with a well-educated workforce as an essential component, are a necessary condition for any economy to achieve a competitive advantage in the international arena. The study objective was to investigate the relationship between the type of education (formal or non-formal) of individuals aged 25-64 and the level of innovation in the European Union member countries. The study uses data provided by Eurostat from three international surveys: The Labor Force Survey (LFS), Adult Education Survey (AES) and Community Innovation Surveys (CIS). The econometric analysis was carried out using tobit regression models.

The study shows that innovation levels of EU countries, as measured by the synthetic SII index strongly depend on 1) the share of people with tertiary education undertaking additional formal or non-formal education, 2) the share of employees undertaking additional formal education, and 3) the share of persons undertaking additional formal or non-formal education. Among the variables studied, the smallest impact on the innovativeness of economies was that of the share of persons undertaking additional formal education. The results indicate a significant and positive role of additional education in increasing the level of innovation and competitiveness in the EU economies.
\end{abstract}

Keywords: adult education, formal education, innovativeness, economic competitiveness, non-formal education JEL Classification: I25, J24, O31

Received: December, 2019

1st Revision: July, 2020

Accepted: July, 2020

\section{INTRODUCTION}

As a result of the endless transformations occurring in advanced economies, macroeconomic focus has broadened towards the intangible factors of production. The main source of wealth has also been shifting from natural assets (land) through measurable produced assets (capital) to- 
wards non-measurable assets (knowledge and information). The transformations that have taken place have changed the understanding of the role of people in the organization, of their role in a company's success, and of their significance for the company's competitive position. The knowledge that employees possess is now recognized as the crucial factor in efficient management of a company, and is also a key factor in the company's success at being innovative (Xu \& Li, 2020; Capozza \& Divella, 2018). Knowledge also constitutes an important factor of the absorption capacity of enterprises and it is complementary to other innovation factors, especially research and development, as conducted independently or in cooperation with other entities. An important role in the long-term growth of innovation is played by human capital, which is broadly defined as human resources, the innovation level of economy, the ability to acquire knowledge capital from abroad, and the exchange of knowledge among companies (Ferraris et al., 2019). This premises represent the basis for the widely acknowledged view that human resources are a key source of competitive advantage (Armstrong \& Taylor, 2014).

The rapid changes taking place in an economy imply that the knowledge and skills of employees is subject to constant depreciation, which places a less favourable light on the relevance of the knowledge employees have obtained at a young age in the formal education system. The latest empirical research on the quality of human capital indicates a positive correlation between human capital and economic growth and development, while most traditional studies using quantitative measures of human capital have offered rather ambiguous results (Morimoto \& Tabata, 2019). It is worth emphasizing, however, that qualitative measures of human capital are based primarily on competence test results (e.g. PISA) carried out at the secondary school level, i.e. among teenagers (Hanushek, 2016). This means that the knowledge and skills of students participating in the studies will become identifiable in the economy with significant delay of at least few years. Also, the education at tertiary level and its impact on economic development, in particular on innovativeness, seems ambiguous and not fully recognized (Vandenbussche et al., 2006). Holmes (2013) has found evidence that mass tertiary education does not necessarily lead to economic growth, as this depends on the teaching quality of universities as well as the ability of graduates to use their acquired knowledge and skills in the workplace. The research to date in this area has generally focused on the relationship between the share of people with formal tertiary education and the increase in real GDP (Dudzevičiūte \& Šimelytė, 2018). Meanwhile, the formal knowledge acquired at university is continuously becoming outdated as new skills and expertise associated with new technologies, etc. are in constant demand. Skills and knowledge require constant upgrading in the form of non-formal education and training, especially in the context of innovation and the competitiveness of economies.

The authors of this study emphasize another important factor improving human capital, namely, non-formal education and training, a factor which so far has not often been included in analyses regarding the innovation of economies. The authors also highlight the fact that in many economies the importance of formal education may be overestimated, while non-formal education may be undervalued, which in the long term may result in an overall weaker innovation performance. The study fills an existing research gap by examining the impact of selected features of human capital development on the innovation levels of EU economies, and consequently their competitiveness. 
The paper is organized as follows. Section 2 contains a theoretical background, while Section 3 introduces the research objective, the data analysis methods and description of data. Section 4 presents the results of the data analysis, with conclusions described in section 5 .

\section{THEORETICAL BACKGROUND}

Many economies continue to reach a higher and higher level of socio-economic development as they take steps to implement features of the so-called knowledge-based economy (Dunning, 2003; Salle, 2010; Dubina et al., 2012). The theoretical basis of the knowledge-based economy is founded upon knowledge, human capital and innovations transferred to the real economy (Hidalgo \& Albors, 2008). The economic growth and competitiveness of developing economies are strongly connected to its innovation status (Terzić, 2017). Human resources are key to this concept - they are responsible for creating, disseminating and using knowledge. The knowledgebased economy is distinguished from the industrial economy of the past by the fact that today's economic growth is less driven by investments in physical infrastructure such as buildings, machinery and equipment, but continues to become more and more dependent on intangible factors such as the ability to generate ideas and accumulate knowledge (Foray \& Lundvall, 2009). A prominent feature of the knowledge-based economy is the transition from an economy dominated by tangible assets to one based on intangibles, which consist mainly of human capital and innovation (Trauth, 2012).

The OECD defines human capital as the knowledge, skills, abilities and other qualities of the human being that enable the generation of personal, social and economic well-being (OECD, 2001). In most definitions, human capital is considered equivalent to the knowledge, skills, abilities and potential for development and introducing innovations, as demonstrated by the people working for a given company (Armstrong \& Taylor, 2014). Youndt \& Snell (2004) perceive human capital as the skills, knowledge and talent that employees use to achieve their own professional and organizational goals. Human capital is integrated with the individual employee, his knowledge, education, abilities, skills, professional predisposition and routines, as well as his entrepreneurship, innovation, relationships with customers, suppliers, colleagues and employer. Additionally, some researchers point out the need to distinguish between the various types of human capital. Parker (2011) distinguishes between general and specific human capital. The general human capital comprises skills, knowledge, experience and capabilities which are useful in a multitude of productive uses and in many places of employment, and which are primarily developed in the course of formal education. The specific capital, on the other hand, refers to skills, experience, knowledge and abilities specific to a particular company acquired in non-formal education, often e.g. during company training regimes.

Sahlberg (2006) claims that human capital is one of the main drivers of economic competitiveness, and improving economic competitiveness requires well-educated and trained personnel. Competitiveness depends on the will and skill of workers to maintain a consistent learning regime, both through self-study and learning from one another. Sahlberg (2006) highlights the general assumption that to increase the competitiveness of a particular economy, the citizenry must acquire the knowledge, skills and attitudes necessary for civic success in terms of the knowledge- 
based economy (David-Hadar, 2018). The literature linking education and competitiveness views education itself as a type of infrastructure for advancing state competitiveness (West, 2012; David-Hadar, 2018). Employees with appropriate knowledge (education, skills, experience) are able to identify and take advantage of the economic opportunities to gain a competitive advantage for their firm. This is confirmed by econometric analyses of the manufacturing sector performed by researchers from Finland (Leiponen, 2005), Germany (Janz \& Peters, 2002; Peters, 2004) and Portugal (Teixeira \& Fortuna, 2006). They demonstrate the complementarity of innovation level and employees' technical skills and the complementarity of scientific cooperation and company employees' skills. What is more, high qualifications of the workforce become a driver of scientific research efficiency and research collaboration. This means that the innovative capacity of firms is dependent on the knowledge of company employees which, in turn, is strongly influenced by the quality, level and types of their formal and non-formal qualifications. The high share of people with tertiary education in the employment structure increases the likelihood of developing and marketing a new product or service and of discovering new markets (Kataoka, 2017).

The analysis of the role of innovation in shaping competitive advantage of economies was initiated by the work of M. Porter in 1990, which is also still the basis of the World Economic Forum's methodology used to quantify the competitiveness. Sedziuviene \& Vveinhardt (2010) showed that organizations open to innovation gain a competitive advantage. Optimization of the organization's finances and human resources (intellectual workforce), as well as the quality of the organization's innovativeness, development and management, acquires competitive importance. The added value of knowledge is revealed in the organization through innovation processes. Competition requires enterprises to constantly innovate and focus on activities with a high knowledge input. The transfer of knowledge between an organization and outside agencies is a horizontal transfer - the transfer of knowledge between a business and its competitors for the purpose of new product development or innovative development, which ultimately leads to improved business performance and competitive advantage (Distanont \& Khongmalai, 2018). While in the past competition was mainly related with quality and affordability, today it is dependent on information, creative novelty, and innovation (Akis, 2015). For this reason, innovations are in the spotlight as a source of improving the competitiveness of companies. The ability to create and assimilate knowledge, produce innovative products and unique services is probably the most important competitive factor in the modern economy.

According to Earle (2010), tertiary education makes the largest contribution to innovation through the knowledge and skills that graduates use at work. Many authors point out that it is necessary to increase the share of technical graduates and to allocate more resources for science and technology as they may stimulate the innovation of economies (Lelek, 2014). High qualifications of workforce are becoming a prerequisite of research effectiveness and of cooperation in research and development. The employees' potential resulting from formal and non-formal education creates the basis and can be an important factor determining the innovation level of economy. However, as was mentioned earlier, knowledge acquired as a result of formal education quickly becomes outdated or, what is worse, insufficient, hence the need for continuous learning. Acquiring new knowledge at a mature age may increase the creativity of employees, which translates into an increase in the company's innovativeness, and consequently that of the entire 
economy. Continuing education includes all the forms of learning that are pursued subsequent to the completion of initial, usually mandatory, education and training. It can generally be pursued in three forms: formal, non-formal and informal.

According to the 2011 International Standard Classification of Education (ISCED), formal (school-based) education is defined as learning within a school system at all levels of education. It is associated with a regular form of education strictly based on the approved education programme, attested by award of a certificate confirming qualifications, a certificate of graduation, course certificate or diploma. Its distinguishing feature is that it is organized by professional teachers, there is a specific curriculum and it often leads to well-defined qualifications (Foley, 2004).

Non-formal (incidental) education is an institutionalized process taking place outside the formal qualifications system, which leads to obtaining qualifications recognized within a given institution (workplace, organization, etc.) or a limited pool of related institutions, but it does not change the level of education. Non-formal education usually leads to the development, extension and acquisition of skills in various areas of professional, social and cultural life. There exist many forms of non-formal education, e.g. courses, workshops and seminars, supervised workplace training and private tuition (Węgrzyn, 2019). It may also include all kinds of conversations, networking and social gatherings which, through the exchange of information, provide knowledge and shape the individual's thinking.

Informal education (learning through practice, self-education) takes place outside the main educational system and is a non-institutionalized, intentional (self-education) or unintentional process. In the latter case, it is a by-product of going through life.

\section{RESEARCH OBJECTIVE, METHODOLOGY AND DATA}

\subsection{Research objective}

The aim of the study is to obtain new empirical results regarding the relationship between the type of further education and training and the innovation levels in the EU member states. The characteristics of human capital - formal and non-formal education - will be analysed in the study.

\subsection{Data analysis methods}

The "tobit model" refers to a class of regression models in which the observed range of the dependent variable is censored. Censoring occurs when the dependent variable is observed only within a certain range of values. When it is not, it is known only to be either above (right-censoring) or below (left-censoring) the censoring. In practice, censoring may result from study design or may be a result of how the outcome is measured.

Tobin (1918) was an American economist who made many outstanding contributions to economics and was awarded the Nobel Prize in 1981. The term „tobit” was coined by Goldberger (1964) in reference to James Tobin, who developed the model in 1958. Tobin (1958) originally conceived the tobit model as one of consumption of consumer durables where purchases were left censored 
in zero. Maddala \& Lahiri (2006) provide an introduction to the tobit model and survey of censored regression models.

The tobit model can be written as the latent regression model:

$y=X \beta+\varepsilon$

with a continuous outcome that is either observed or unobserved. The tobit model assumes that the error term is normally distributed: $\varepsilon \sim N\left(0, \sigma^{2} \mathrm{I}\right)$. Following Cong (2000), the observed outcome for observation $i$ is defined as

$y_{i}^{*}= \begin{cases}y_{i} & \text { if } y_{i} \in(a ; b) \\ a & \text { if } y_{i} \leq a \\ b & \text { if } y_{i} \geq b\end{cases}$

where $\mathrm{a}$ is the lower-censoring limit, $\mathrm{b}$ is the upper-censoring limit. In case of the Summary Innovation Index, the lower limit is equal to 0 and the upper limit to 100.

In this study, the statistical inference is performed with the help of bootstrap tests as they usually yield more accurate inferences than asymptotic tests (Horowitz, 1997). When a standard asymptotic test is available, the corresponding bootstrap test is often found to provide a better finite sample approximation and the improvement is sometimes remarkable. Stewart (1997) and Dufour \& Khalaf (2002) showed that bootstrap tests may be particularly useful in the case of multivariate regression models, because standard asymptotic tests often over-reject severely. In this paper, bootstrap estimation was used to get the variance-covariance matrix corresponding to the parameter estimates and the reported standard errors are the square root of the diagonal elements of the variance-covariance matrix.

Since in this study many competing models are estimated, the problem of models' comparison and selection is unavoidable. Model selection is the problem of choosing the best one from among a set of candidate models. For this purpose, a widely known Bayesian Information Criterion (BIC) is employed. When choosing from several models, the one with the lowest BIC is preferred. The BIC is an increasing function of the model error variance and an increasing function of the number of explanatory variables. That is, unexplained variation in the dependent variable and the number of explanatory variables increase the value of BIC. In this case, lower BIC implies better fit. The strength of the evidence against the baseline model can be summarized as follows: $\triangle \mathrm{BIC}$ from 0 to 2 - almost no evidence, 2 to 6 - positive evidence, 6 to 10 - strong evidence, above 10 - very strong evidence (Kass \& Raftery, 1995).

\subsection{Data}

The study makes use of secondary data from the Eurostat database and covers the European Union, i.e. its 28 member states. The data come from two international studies - The Labor Force Survey (LFS) and Adult Education Survey (AES). The LFS survey provides an ongoing assessment of the labour resources activity in the EU member countries and covers people aged 15 and over. The AES study, on the other hand, deals with participation in formal, non-formal and informal education within the 12 months preceding the survey among people aged 25-64. The AES survey has been carried out three times so far: in 2007, 2011 and 2016. The innovation 
levels in economies were assessed by means of the SII (Summary Innovation Index) calculated on the basis of data from the international Community Innovation Surveys (CIS). For example, SII was used previously to assess the level of innovation in economies by Shqipe \& Ramadani (2010) and Szabo \& Herman (2012). The SII builds upon the four types of indicators (referred to by the index creators as framework conditions, investments, innovation activities, impacts) in ten areas. In total, the SII is an aggregate of a set of 27 sub indicators representing individual aspects of innovation (European Commission, 2019). Finally, only the 2011 and 2016 data were used in the study, as the Eurostat database lacks the 2007 SII values adjusted according to the latest methodology, i.e. SII 2019. In our research, the SII is a dependent variable.

Three determinants of innovation (D1-D3), typically considered in the literature, were used as a foundation of the tobit regression models (Table 1). The literature indicates that people with tertiary education (D1) bring not only a higher rate of economic innovation but also a higher pace of technology transfer (Bilbao-Osorio \& Rodriguez-Pose, 2004, Armstrong \& Taylor, 2014). Along with the growing importance of science and technology in the economy, human resources employed in the scientific and technical sphere, i.e. Human Resources for Science and Technology (HRST), play also an increasingly important role (D2). These are people who have a university degree in science and technology and who are engaged or potentially can engage in work related to the creation, development, dissemination and application of scientific and technical knowledge. The third key factor (D3) determining innovation and thus the competitiveness of economies is intramural R\&D expenditure (for example, aimed at developing and implementing new technologies) expressed as a percentage of GDP (Kiselakova et al., 2018; Morimoto \& Tabata, 2019). The other independent variables (X1-X9) are directly related to the research objective.

Tab. 1 - Predictor codenames and descriptions for the analysed independent variables. Source: own research

\begin{tabular}{|c|c|}
\hline Codename & Description \\
\hline D1 & Persons with tertiary education as $\%$ of total population. \\
\hline D2 & $\begin{array}{l}\text { Persons with tertiary education employed in science and technology (HRST) } \\
\text { as } \% \text { of total employment. }\end{array}$ \\
\hline D3 & Intramural R\&D expenditure as \% of GDP. \\
\hline $\mathrm{X} 1$ & $\begin{array}{l}\text { Participation rate ( } \% \text { of } 25-64 \mathrm{y} / \mathrm{o}) \text { in formal and non-formal education and } \\
\text { training. }\end{array}$ \\
\hline $\mathrm{X} 2$ & Participation rate (\% of $25-64 \mathrm{y} / \mathrm{o})$ in formal education and training. \\
\hline $\mathrm{X} 3$ & Participation rate ( $\%$ of $25-64 \mathrm{y} / \mathrm{o})$ in non-formal education and training. \\
\hline $\mathrm{X} 4$ & $\begin{array}{l}\text { Participation rate ( } \% \text { of } 25-64 \mathrm{y} / \mathrm{o}) \text { in formal and non-formal education and } \\
\text { training of people with tertiary education only. }\end{array}$ \\
\hline $\mathrm{X} 5$ & $\begin{array}{l}\text { Participation rate ( } \% \text { of } 25-64 \text { y/o) in formal education and training of em- } \\
\text { ployed persons only. }\end{array}$ \\
\hline X6 & $\begin{array}{l}\text { Participation rate ( } \% \text { of } 25-64 \text { y/o) in job-related non-formal education and } \\
\text { training. }\end{array}$ \\
\hline
\end{tabular}




\begin{tabular}{|l|l|}
\hline X7 & $\begin{array}{l}\text { Participation rate }(\% \text { of } 25-64 \mathrm{y} / \mathrm{o}) \text { in job-related non-formal education and } \\
\text { training of people with tertiary education only. }\end{array}$ \\
\hline X8 & $\begin{array}{l}\text { Participation rate }(\% \text { of } 25-64 \mathrm{y} / \mathrm{o}) \text { in job-related non-formal education and } \\
\text { training of employed persons only. }\end{array}$ \\
\hline X9 & $\begin{array}{l}\text { Participation rate }(\% \text { of } 25-64 \mathrm{y} / \mathrm{o}) \text { in job-related non-formal education and } \\
\text { training sponsored by the employer. }\end{array}$ \\
\hline
\end{tabular}

\section{RESULTS}

For each of the variables analysed, their descriptive statistics, such as minimum, maximum, range (calculated as the difference between the maximum and minimum values), mean, standard deviation, kurtosis and skewness are presented in Table 2. The SII can theoretically take values from 0 to 100. The lowest value (15) of the SII was noted for Romania in 2016, while the highest value of 71.3 was that for Sweden. The average SII value for the EU countries for 2011 and 2016 in total was 43.82. The standard deviation was 15.08, which indicates the mean spread around the mean SII for individual EU countries (in 2011 and 2016). A negative kurtosis (-1.21) indicates a moderate flatness of the distribution of the SII as compared to the normal distribution. It can be seen that the skewness is close to zero (0.12), which means that the distribution of SII values is almost symmetrical. For the remaining variables, which in the study played the role of explanatory (independent) variables, the lowest values were the most common for Romania, with the exception of the D3 variable, the lowest value of which was recorded for Latvia in 2016. The highest values most often occurred in Sweden, with the exceptions of the D1 variable, whose maximum value was found in Ireland in 2016, the D2 variable, whose maximum value was noted in Luxembourg in 2016, D3 in Finland in 2011, X2 in the UK in 2011, and X3 and X5 in Luxembourg in 2011. Distributions of the explanatory variables, with the exception of D1, were generally asymmetric. In most cases, it was left-tailed asymmetry, which indicates that most countries had values above the average. The exceptions were the variables D2, D3 and X2, of which most countries had lower than average values.

Tab. 2 - Descriptive statistics of SII, D1, D2, D3 and X1-X9 variables. Source: own research

\begin{tabular}{|l|l|l|l|l|l|l|l|}
\hline Variable & $\begin{array}{l}\text { Mini- } \\
\text { mum }\end{array}$ & $\begin{array}{l}\text { Maxi- } \\
\text { mum }\end{array}$ & Range & Mean & $\begin{array}{l}\text { Standard } \\
\text { deviation }\end{array}$ & Kurtosis & Skewness \\
\hline SII & 15.00 & 71.30 & 56.30 & 43.82 & 15.08 & -1.21 & 0.12 \\
\hline D1 & 14.60 & 45.10 & 30.50 & 29.78 & 8.54 & -1.16 & -0.11 \\
\hline D2 & 32.10 & 60.80 & 28.70 & 44.34 & 6.77 & -0.34 & 0.38 \\
\hline D3 & 0.44 & 3.64 & 3.20 & 1.56 & 0.89 & -0.72 & 0.64 \\
\hline X1 & 7.00 & 71.80 & 64.80 & 41.97 & 14.43 & 0.09 & -0.39 \\
\hline X2 & 1.40 & 14.80 & 13.40 & 6.31 & 3.75 & -0.41 & 0.82 \\
\hline X3 & 5.60 & 68.00 & 62.40 & 38.97 & 14.10 & -0.03 & -0.39 \\
\hline X4 & 15.80 & 84.90 & 69.10 & 61.81 & 14.95 & 1.59 & -1.31 \\
\hline X5 & 8.20 & 79.20 & 71.00 & 50.47 & 14.98 & 1.12 & -0.83 \\
\hline
\end{tabular}




\begin{tabular}{|l|l|l|l|l|l|l|l|}
\hline X6 & 4.00 & 58.70 & 54.70 & 32.97 & 11.98 & 0.09 & -0.40 \\
\hline X7 & 10.50 & 72.70 & 62.20 & 50.38 & 13.60 & 1.27 & -1.12 \\
\hline X8 & 5.70 & 69.10 & 63.40 & 43.22 & 13.54 & 0.96 & -0.78 \\
\hline X9 & 3.40 & 55.90 & 52.50 & 29.34 & 11.72 & 0.01 & -0.32 \\
\hline
\end{tabular}

Tables 3 and 4 contain results of estimation of the tobit regression models. There are nine regular models and one benchmark model which is the reference point for the others. The benchmark model includes only three independent variables (D1-D3) which, according to the literature review and economic theory, should be strong determinants of the innovation levels in the EU countries. As for the other variables (X1-X9), there is no such certainty, so the purpose of the study was to verify which of them - and to what extent - are related to innovation as measured with the SII index. Each of the nine models includes only one additional variable over those found in the benchmark model. Regression coefficients (presented in the row marked Xi in Tables 3 and 4) determine for each of these variables the increase of dependent variable as predicted by the model corresponding to the unit increase in the independent variable (Xi), with the assumption of other variables in the model remaining unchanged. However, as the results from Table 2, the independent variables analysed are characterized by widely varying ranges of values. Consequently, direct comparison of regression coefficients can be misleading. Therefore, to make the results comparable the model's expected increase in the dependent variable value was calculated with the assumptions that the independent variable increases by $25 \%$ of its range. The obtained measure is given in Tables 3-4 as Scaled Impact and is illustrated in Figure 1. Based on this measure, it is possible to infer the strength and direction of the impacts of individual predictors, as well as to compare them with each other (Nimon \& Oswald, 2013; Landis, 2005). As a supplement to the Scaled Impact measure, $\triangle \mathrm{BIC}$ was also determined for each predictor (Figure 2), which is a common method of comparing the predictive ability of different models.

As mentioned above, only three explanatory variables have been included in Model 0: D1, D2 and D3. The study confirmed the impact of D1 and D3 on SII (in both cases, p < 0.01). An increase in the share of people with tertiary education by 1 pp causes an average increase in the dependent variable by 0.611 with constant levels of D2 and D3, while an increase in domestic $\mathrm{R} \& \mathrm{D}$ expenditure (as \% of GDP) by 1 pp would increase the dependent variable by 12.11 on average, with constant levels of D1 and D2. The D1 and D3 also remained statistically significant at the 0.01 level in the other models considered. In Model 0, only the D2 variable showed no statistically significant impact on the dependent variable, while the statistical significance of its impact was noted in all other models except for Model 2. The Year indicator (with the value of 0/1 for the year 2011/2016) showed no statistically significant differences in the average levels of the dependent variable in both periods in all the models considered. 


\section{Scaled Impact}

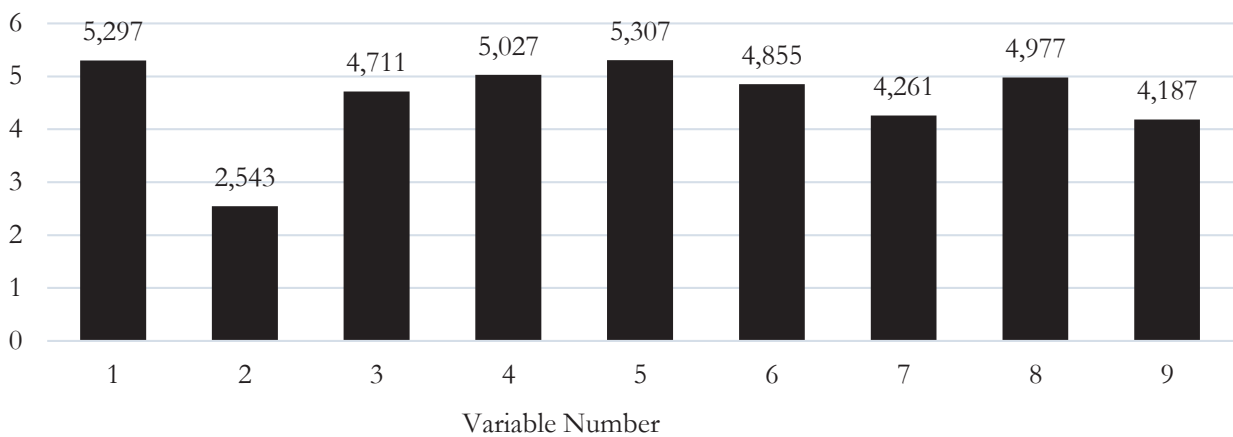

Fig. 1 - Scaled impact of X1-X9 variables. Source: own research

Tab. 3 - Tobit regression models. Source: own research

\begin{tabular}{|c|c|c|c|c|c|}
\hline \multirow[t]{2}{*}{ Predictors } & \multicolumn{5}{|c|}{ Tobit regression models } \\
\hline & Model 0 & Model 1 & Model 2 & Model 3 & Model 4 \\
\hline D1 & $\begin{array}{l}0.611 * * * \\
(0.128)\end{array}$ & $\begin{array}{l}0.471 * * * \\
(0.121)\end{array}$ & $\begin{array}{l}0.481 * * * \\
(0.141)\end{array}$ & $\begin{array}{l}0.506^{* * *} \\
(0.121)\end{array}$ & $\begin{array}{l}0.575^{* * *} \\
(0.110)\end{array}$ \\
\hline D2 & $0.157(0.145)$ & $\begin{array}{l}0.271 * * \\
(0.109)\end{array}$ & $0.045(0.158)$ & $\begin{array}{l}0.283^{* *} \\
(0.111)\end{array}$ & $\begin{array}{l}0.316^{* * *} \\
(0.107)\end{array}$ \\
\hline D3 & $\begin{array}{l}12.110^{* * *} \\
(1.019)\end{array}$ & $\begin{array}{l}9.149 * * * \\
(1.134)\end{array}$ & $\begin{array}{l}10.830^{* * *} \\
(1.164)\end{array}$ & $\begin{array}{l}9.543^{* * *} \\
(1.108)\end{array}$ & $\begin{array}{l}9.512^{* * *} \\
(1.097)\end{array}$ \\
\hline \multirow[t]{2}{*}{$\mathrm{Xi}$} & -- & $\mathrm{X} 1$ & $\mathrm{X} 2$ & $\mathrm{X} 3$ & $\mathrm{X} 4$ \\
\hline & & $\begin{array}{l}0.327 * * * \\
(0.076)\end{array}$ & $\begin{array}{l}0.759 * * * \\
(0.292)\end{array}$ & $\begin{array}{l}0.302^{* * *} \\
(0.077)\end{array}$ & $\begin{array}{l}0.291 * * * \\
(0.065)\end{array}$ \\
\hline $\mathrm{C}$ & $0.205(7.056)$ & $-9.390(5.849)$ & $5.904(7.740)$ & $-9.517(5.997)$ & $\begin{array}{l}-19.430 * * * \\
(6.569)\end{array}$ \\
\hline Year & $-1.069(1.943)$ & $-1.779(1.671)$ & $-0.317(1.947)$ & $-1.959(1.720)$ & $-1.500(1.694)$ \\
\hline Pseudo R 2 & 0.2085 & 0.2468 & 0.2206 & 0.2421 & 0.2506 \\
\hline Sigma & 6.326 & 5.401 & 6.019 & 5.509 & 5.319 \\
\hline $\mathrm{LL}$ & -182.758 & -173.914 & -179.978 & -175.016 & -173.058 \\
\hline $\mathrm{BIC}$ & 389.669 & 376.005 & 388.134 & 378.209 & 374.293 \\
\hline$\Delta \mathrm{BIC}$ & 0 & 13.664 & 1.535 & 11.460 & 15.376 \\
\hline $\begin{array}{l}\text { Scaled } \\
\text { Impact }\end{array}$ & - & 5.297 & 2.543 & 4.711 & 5.027 \\
\hline
\end{tabular}

Notes: *** denotes statistical significance of the regression coefficient at $1 \%$, ** at $5 \%, *$ at $10 \%$. Year is a dummy variable for observations from the year 2016; $\mathrm{C}$ is an intercept; sigma is the estimated standard error of the regression; LL - log-likelihood; BIC - Bayesian Information Criterion; $\Delta \mathrm{BIC}$ for the i-th model is the dif- 
ference between the BIC for model "i" and for model 0 . The scaled impact of variable $\mathrm{Xi}$ is a predicted change in the dependent variable caused by an increase of the independent variable $\mathrm{Xi}$ by $25 \%$ of its range. The bootstrap standard errors are in parentheses.

Tab. 4 - Tobit regression models (continued). Source: own research

\begin{tabular}{|c|c|c|c|c|c|}
\hline \multirow[t]{2}{*}{ Predictors } & \multicolumn{5}{|c|}{ Tobit regression models } \\
\hline & Model 5 & Model 6 & Model 7 & Model 8 & Model 9 \\
\hline D1 & $\begin{array}{l}0.458^{* * *} \\
(0.113)\end{array}$ & $\begin{array}{l}0.511 * * * \\
(0.119)\end{array}$ & $\begin{array}{l}0.596 * * * \\
(0.116)\end{array}$ & $\begin{array}{l}0.484^{* * *} \\
(0.112)\end{array}$ & $\begin{array}{l}0.530 * * * \\
(0.123)\end{array}$ \\
\hline D2 & $\begin{array}{l}0.295^{* * *} \\
(0.112)\end{array}$ & $\begin{array}{l}0.267 * * \\
(0.112)\end{array}$ & $\begin{array}{l}0.284^{* *} \\
(0.115)\end{array}$ & $\begin{array}{l}0.281 * * \\
(0.115)\end{array}$ & $\begin{array}{l}0.239 * * \\
(0.117)\end{array}$ \\
\hline D3 & $\begin{array}{l}9.729 * * * \\
(1.060)\end{array}$ & $\begin{array}{l}9.517 * * * \\
(1.087)\end{array}$ & $\begin{array}{l}9.947 * * * \\
(1.116)\end{array}$ & $\begin{array}{l}9.781 * * * \\
(1.055)\end{array}$ & $\begin{array}{l}9.792 * * * \\
(1.145)\end{array}$ \\
\hline $\mathrm{Xi}$ & $\mathrm{X} 5$ & $\mathrm{X} 6$ & $\mathrm{X} 7$ & $\mathrm{X} 8$ & $\mathrm{X} 9$ \\
\hline & $\begin{array}{l}0.299 * * * \\
(0.062)\end{array}$ & $\begin{array}{l}0.355^{* * *} \\
(0.083)\end{array}$ & $\begin{array}{l}0.274 * * * \\
(0.072)\end{array}$ & $\begin{array}{l}0.314 * * * \\
(0.062)\end{array}$ & $\begin{array}{l}0.319 * * * \\
(0.092)\end{array}$ \\
\hline $\mathrm{C}$ & $\begin{array}{l}-12.658^{* *} \\
(6.123)\end{array}$ & $-8.839(6.057)$ & $\begin{array}{l}-15.021^{* *} \\
(6.938)\end{array}$ & $\begin{array}{l}-11.269 * \\
(6.207)\end{array}$ & $-6.319(6.208)$ \\
\hline Year & $-1.167(1.666)$ & $-2.024(1.715)$ & $-1.773(1.754)$ & $-1.266(1.697)$ & $-1.838(1.773)$ \\
\hline Pseudo R ${ }^{2}$ & 0.2485 & 0.2422 & 0.2398 & 0.2447 & 0.2344 \\
\hline Sigma & 5.366 & 5.505 & 5.561 & 5.449 & 5.686 \\
\hline LL & -173.543 & -174.982 & -175.546 & -174.407 & -176.786 \\
\hline $\mathrm{BIC}$ & 375.263 & 378.142 & 379.269 & 376.992 & 381.750 \\
\hline$\Delta \mathrm{BIC}$ & 14.406 & 11.5269 & 10.400 & 12.677 & 7.919 \\
\hline $\begin{array}{l}\text { Scaled Im- } \\
\text { pact }\end{array}$ & 5.307 & 4.855 & 4.261 & 4.977 & 4.187 \\
\hline
\end{tabular}

Notes: ibid. Tab. 3.

For all independent X1-X9 variables in the regression models, statistically significant regression coefficients corresponding to these variables were observed. In each case, $\mathrm{p}<0.01$, and the regression coefficients were positive, indicating a positive impact of independent X1-X9 variables on the dependent variable. Figure 1 shows that except for the X2 the Scaled Impact was between 4.2 and 5.3. The analysis of $\triangle \mathrm{BIC}$ provides practically identical conclusions. The $\mathrm{X} 2$ variable demonstrated by far the lowest value. Also, in comparison to other variables, the $\mathrm{X} 7$ and $\mathrm{X} 9$ demonstrate moderately lower values of Scaled Impact and $\Delta \mathrm{BIC}$. 


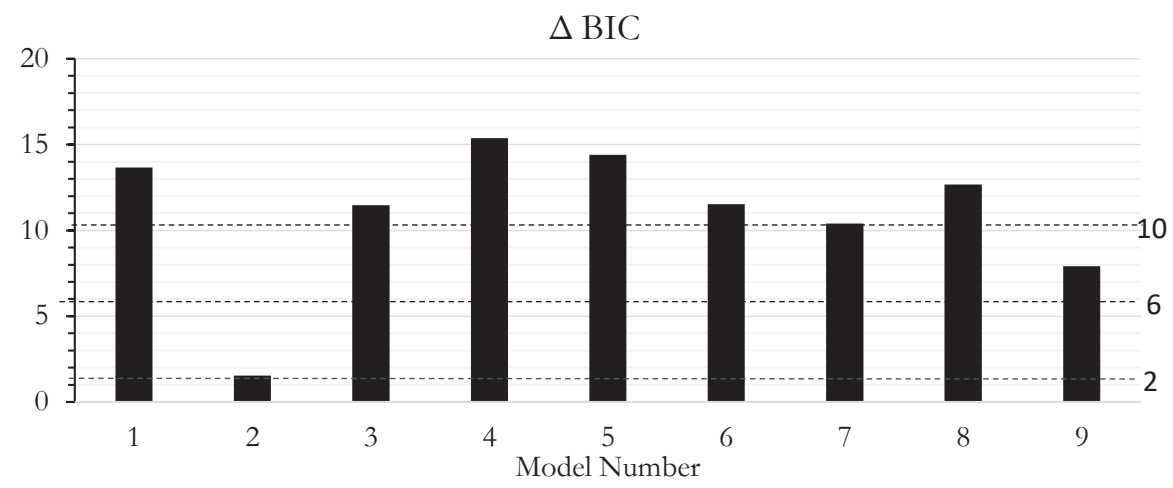

Fig. 2 - The Delta BIC (Bayesian Information Criterion) values for tobit regression models. Source: own research

\section{DISCUSSION AND CONCLUSION}

Our study has shown that innovation levels of EU member countries as measured by the synthetic SII index (among the X1-X9 variables considered) strongly depend on: 1 ) the share (\% of 25-64 y/o) of people with tertiary education undertaking additional formal or non-formal education (X4), 2) the share of employees undertaking additional formal education (X5), and 3) the share of persons undertaking additional formal or non-formal education (X1). The study has also confirmed the impact of the share of people with tertiary education in the general population on innovation levels (D1), a finding which has already been recognized in the subject literature. These results are in line with research by Earle (2010) which demonstrates that it is the knowledge and skills of employees with tertiary education that translate into innovation; our findings also support Sahlberg's (2006) assertion that innovativeness and competitiveness depend on the will and skill of workers to maintain self-study habits. Additionally, our study has shown more than this: it indicates the substantial impact of the share of people already with tertiary education continuing their post-tertiary education on the growth of innovation. Nevertheless, among the examined X1-X9 variables, the weakest impact on the innovativeness of economies was that of the share of people undertaking additional formal education (X2). Knowledge acquired as a result of continued formal education has proven to have the weakest, albeit still positive, impact on the levels of innovation of EU member countries. This confirms Adams' (2005) opinion that "despite the existence of so many creativity training programmes and efforts, in the formal education system current classroom practices do not focus enough on promoting creativity and innovation and even sometimes serve to destroy it." Our obtained results also to a degree corroborate the relationship between new knowledge and innovations and competitive advantage demonstrated by Sedziuviene \& Vveinhardt (2010).

Similar conclusions on the importance of skills (proxied by inter alia, educational levels) for increasing innovation were drawn up for Finnish companies by Leiponen (2005). The relevance of education on economic development in Italy was studied by Agasisti et al. (2019), who showed a link between the performance of universities and the economic development of the regions 
in which they operate; based on the data set of 53 Italian public universities observed over the years 2006-2012, these findings revealed that the presence of efficient universities fosters local economic development. Universities boost local economic development via knowledge transfer through education and human resources development, via knowledge creation and regional innovation through research, and via technology transfer activities. The relationship between higher education measured by the quality of universities (as indicated by the Shanghai Jiao Tong rankings) and the competitiveness of countries (competitiveness index taken from The World Economic Forum's Global Competitiveness Report 2012-2013) was examined by Cabrera \& Le Renard (2015). These researchers found a strong correlation between the number of top research universities per capita in a given country with the level of competitiveness of that country. The role of education in regional innovation activities was examined by Chi \& Qian (2010), who used Chinese provincial data from 1997 to 2006. They found that the level of workers' tertiary education was significantly and positively related to provincial innovative activities as measured by invention patent applications per capita. They also found strong evidence for the prediction related to the endogenous growth theory about the positive effect of human capital on innovation. Saad et al. (2014) investigated the role of the higher education system in the stimulation of national innovation. Here the innovation performance of a country was measured by the annual average of patent families between 2005 and 2008. Patents were used as a proxy for innovation due to the lack of directly measured innovation data. Nevertheless, patent output is correlated with innovation, and therefore should be a good indicator of the relative innovation performance of nations. The dataset of Saad et al. (2014) consisted of 208 countries. The authors concluded that focus should be placed on increasing access to and investment in higher education, as well as lowering subsidies, as the latter was found to have an adverse effect on patent production.

In general, our results indicate a significant and positive role of additional education in increasing the level of innovation and competitiveness of modern economies, especially for people already possessing tertiary education. The countries where a significant proportion of labour force is involved in lifelong learning achieve a higher level of competitiveness than those with a lower level of this educational activity. In the era of knowledge-based economies, competitive advantages are increasingly seen to be based on intangible resources such as the formal and non-formal education of employees, which in turn directly and indirectly creates innovation. The level of employee education as well as their current knowledge determine their propensity to create and implement innovations.

A worthwhile subject for future research would be the further identification of factors affecting innovation and thus competitiveness of economies, especially in relation to more detailed decomposition of the education structure.

Some limitations related to our study might be identified which stem mainly from issues of data sparsity. The appropriate survey data collection began in 2011 and the data was gathered irregularly, i.e. the surveys took place about 4-5 years apart. This caused the fact the measurement of the relationships between variables was mainly a result of the cross-sectional data analysis. For more robust results and deeper insights, a longer series of longitudinal data would be preferred. 


\section{References}

1. Adams, K. (2005). The Sources of Innovation and Creativity. NCEE, Washington.

2. Agasisti T., Barra C., \& Zotti R. (2019). Research, knowledge transfer, and innovation: The effect of Italian universities' efficiency on local economic development 2006-2012. Journal of Regional Science, 59 (5), 819-849. https://doi.org/10.1111/jors.12427

3. Akis E. (2015). Innovation and Competitive Power. Procedia - Social and Behavioral Sciences, 195, 1311-1320.

4. Armstrong, M., \& Taylor S. (2014). Armstrong's Handbook of Human resource Management Practice. Thirteenth edition, KoganPage. London.

5. David-Hadar, B. (2018). Education Finance, Equality, and Equity. Springer International Publishing, New York: New York City.

6. Bilbao-Osorio, B. \& Rodríguez-Pose A. (2004). From R\&D to Innovation and Economic Growth in the EU. Growth and Change, 35 (4), 434-55.

7. Cabrera, A. \& Le Renard, C. (2015). Internationalization, Higher Education, and Competitiveness. In: New Perspectives on Internationalization and Competitiveness. Integrating Economics, Ullberg E. (Ed.). Innovation and Higher Education, Springer, 11-16.

8. Cong, R. (2000). Marginal effects of the tobit model. Stata Technical Bulletin, 56: 27-34. Reprinted in Stata Technical Bulletin Reprints, 10, 189-197. College Station, TX: Stata Press.

9. Distanont, A., \& Khongmalai, O. (2018). The role of innovation in creating a competitive advantage. Kasetsart Journal of Social Sciences, 41 (1), 15-21. https://doi.org/10.1016/j. kjss.2018.07.009

10. Capozza, C., \& Divella, M. (2019). Human capital and firms' innovation: evidence from emerging economies. Economics of Innovation and New Technology, 28 (7), 741-757. https://doi.org/ $10.1080 / 10438599.2018 .1557426$

11. Chi W., \& Qian X. (2010). The role of education in regional innovation activities: spatial evidence from China. Journal of the Asia Pacific Economy, 15 (4), 396-419. https://doi.org/10.1080 $/ 13547860.2010 .516158$

12. Dubina, I. N., Carayannis, E. G., \& Campbell, D. F. J. (2012). Creativity Economy and a Crisis of the Economy? Coevolution of Knowledge, Innovation, and Creativity, and of the Knowledge Economy and Knowledge Society. Journal of the Knowledge Economy, 3 (1), 1-24. https://doi.org/10.1007/s13132-011-0042-y

13. Dudzevičiūtè, G., \& Šimelytè, A. (2018). Education and Economic Development in the Selected European Union Countries. European Journal of Sustainable Development, 7 (2), 14-28, https://doi.10.14207/ejsd.2018.v7n2p14

14. Dufour, J.-M., \& Khalaf, L. (2002). Simulation based finite and large sample tests in multivariate regressions. Journal of Econometrics, 111, 303-322.

15. Dunning J. H. (2003). Regions, Globalization, and the Knowledge-Based Economy, OXFORD University Press. 
16. Earle, D. (2010). How can tertiary education deliver better value to the economy? Tertiary education occasional paper. http://thehub.superu.govt.nz/sites/default/files/41943_value-oftertiaryeducation_0.pdf

17. European Commission. (2019). European Innovation Scoreboard 2019 - Methodology Report. Retrieved from: https://ec.europa.eu/growth/industry/policy/innovation/ scoreboards_en

18. Ferraris, A., Devalle, A., Ciampi, F., \& Couturier, J. (2019). Are global R\&D partnerships enough to increase a company's innovation performance? The role of search and integrative capacities. Technological Forecasting and Social Change, 149, 119750. https://doi.org/10.1016/j. techfore. 2019.119750

19. Foley, A. (2004). Dimensions of Adult Learning. Adult education and training in a global era. Open University Press.

20. Foray D., \& Lundvall B. A. (2009), The knowledge-based economy: From the economics of knowledge to the learning economy. Oxford, UK: Taylor and Francis, 115-122.

21. Goldberger, A. S. (1964). Econometric Theory. New York: J. Wiley.

22. Hanushek, E. A. (2016). Will higher education improve economic growth? Oxford Review of Economic Policy, 32, 538-552. https://doi:10.1093/oxrep/grw025

23. Hidalgo A., \& Albors J. (2008). Innovation management techniques and tools: A review from theory and practice. $R$ and D Management, 38 (2) 113-127. https://doi.org/10.1111/j.14679310.2008.00503.x

24. Holmes, C. (2013). Has the Expansion of Higher Education Led to Greater Economic Growth? National Institute Economic Review, 224, 29-47. https://doi.org/10.1177\% 2F002795011322400103

25. Horowitz, J. L. (1997). Bootstrap methods in econometrics: theory and numerical performance. Advances in Economics and Econometrics: Theory and Applications, vol. 3, ed. D. M. Kreps and K. F. Wallis, Cambridge, Cambridge Univ. Press.

26. Janz, N., \& Peters, B. (2002). Innovation and innovation success in the German manufacturing sector, econometric evidence at firm level. Centre for European Economic Research (ZEW) Department of Industrial Economics and International Management, Mannheim, Germany.

27. Kataoka, M. (2018). Correction to: Inequality convergence in inefficiency and interprovincial income inequality in Indonesia for 1990-2010. Asia-Pacific Journal of Regional Science, 2 (2), 315-315. http://doi:10.1007/s41685-017-0051-3

28. Kass, R. E., \& Raftery, A. E. (1995), Bayes Factors. Journal of the American Statistical Association, 90 (430), 773-795.

29. Kiselakova, D., Sofrankova, B., Cabinova, V., Onuferova, E., \& Soltesova, J. (2018). The Impact of R\&D Expenditure on the Development of Global Competitiveness within the CEE EU Countries. Journal of Competitiveness, 10 (3), 34-50. https://doi.org/10.7441/joc.2018.03.03

30. Landis R. S. (2005). Standardized Regression Coefficients. In: Encyclopedia of Statistics in Behavioral Science, 4, 1892-1892. John Wiley \& Sons, Ltd, Chichester. 
31. Leiponen, A. (2005). Skills and innovation. International Journal of Industrial Organization, 23, 303-323.

32. Lelek, T. (2014). Trend Analysis of Human Resources Development Representing the Base for Researchers in Selected Economies. Journal of Competitiveness, 6 (1), 71-86. https://doi. org/10.7441/joc.2014.01.05

33. Maddala, G. S., \& Lahiri, K. (2006). Introduction to Econometrics. 4th ed. New York: Wiley. McDonald, J. F., and R. A. Moffitt. 1980. The use of tobit analysis. Review of Economics and Statistics, 62 .

34. Morimoto T., \& Tabata K., (2019). Higher Education Subsidy Policy and R\&D-based Growth. Macroeconomics Dynamics. 1-40. https://doi.org/10.1017/S1365100519000142

35. Nimon K. F., \& Oswald F. L., (2013). Understanding the Results of Multiple Linear Regression: Beyond Standardized Regression Coefficients. Organizational research methods, 16 (4), 650-674. https://doi.org/10.1177/1094428113493929

36. OECD. (2001). The Well-being of Nations. The Role of Human and Social Capital. Retreived from: http://www.oecd.org/dataoecd/36/40/33703702.pdf

37. Parker, S. C. (2011). Intrapreneurship or entrepreneurship? Journal of Business Venturing, 26 (1), 19-34. https://doi.org/10.1016/j.jbusvent.2009.07.003

38. Peters, B. (2004). Employment Effects of Different Innovation Activities: Microeconometric Evidence. Zentrum für Europäische Wirtschaftsforschung GmbH, Discussion Paper No. 04-73.

39. Saad, M., Guermat C., \& Brodie L. (2014). National innovation and knowledge performance: the role of higher education teaching and training. Studies in Higher Education, 40 (7), 1-16. https://doi.org/10.1080/03075079.2014.881344

40. Sahlberg, P. (2006). Education reform for raising economic competitiveness. Journal of Educational Change, 7, 259-287. https://doi.org/10.1007/s10833-005-4884-6

41. Salle R. (2010). Human capital and economic growth. Cambridge University Press, 71-86.

42. Sedziuviene N., \& Vveinhardt J. (2010). Competitiveness and Innovations: Role of Knowledge Management at a Knowledge Organization. Inzinerine Ekonomika-Engineering Economics, 21 (5), $525-536$.

43. Shqipe G. \& Ramadani V. (2010). The Impact of Innovation into the Economic Growth. MPR A Paper No. 22270.

44. Stewart, K. G. (1997). Exact testing in multivariate regression. Econometric Reviews, 16, 321-352.

45. Szabo K. Z. \& Herman E. (2012), Innovative Entrepreneurship for Economic Development in EU. Procedia Economics and Finance, 3, 268-275. https://doi.org/10.1016/S2212-5671(12)001517

46. Teixeira, A., \& Fortuna, N. (2006). Human capital, trade and long-run productivity. Testing the technological absorption hypothesis for the Portuguese economy, 1960-2001. FEP Working Papers.

47. Terzić L. (2017). The Role of Innovation in Fostering Competitiveness and Economic 
Growth: Evidence from Developing Economies. Comparative Economic Research, 4 (21), 65-81. https://doi.org/10.1515/cer-2017-0028

48. Tobin, J. (1958). Estimation of relationships for limited dependent variables. Econometrica, 26, $24-36$.

49. Trauth, E. M. (2012). Barriers to knowledge acquisition, transfer and management in regional knowledge economy development. In Proceedings of the Annual Hawaii International Conference on System Sciences 2011, 3612-3621. Retrieved from http://ieeexplore.ieee.org/ stamp/stamp.jsp?tp $=$ \&arnumber $=6149137$

50. Vandenbussche, J., Aghion, P., \& Meghir C. (2006). Growth, distance to frontier and composition of human capital. Journal of Economic Growth, 11, 97-127.

51. Węgrzyn, G. (2019). Adult Education as a Factor Increasing the Innovativeness of European Union Countries. Studies of the Industrial Geography Commission of the Polish Geographical Society, 33 (2), 18-31. http://dx.doi.org/10.24917/20801653.332.2

52. West, M. R. (2012). Education and global competitiveness. In Hassett K. (Ed.), Rethinking competitiveness. Washington, DC: American Enterprise Institute Press.

53. Xu, Y., \& Li, A. (2020). The relationship between innovative human capital and interprovincial economic growth based on panel data model and spatial econometrics. Journal of Computational and Applied Mathematics, 365. 112381. https://doi.org/10.1016/j.cam.2019.112381

54. Youndt, M. A., Subramaniam, M., \& Snell, S. A. (2004). Intellectual Capital Profiles: An Examination of Investments and Returns. Journal of Management Studies, 41 (2), 335-361. https:// doi.org/10.1111/j.1467-6486.2004.00435.x

\section{Contact information}

Sabina Denkowska, Ph.D.

Cracow University of Economics

College of Economics, Finance and Law

Poland

E-mail: sabina.denkowska@uek.krakow.pl

ORCID: 0000-0003-4663-8010

Kamil Fijorek, Ph.D.

Cracow University of Economics

College of Economics, Finance and Law

Poland

E-mail:kamil.fijorek@uek.krakow.pl

ORCID: 0000-0003-1262-6425
Grazyna Wegrzyn, associate professor

Wroclaw University of Economics and Business

Faculty of Economics and Finance

Department of Economics and Economic Policy

Poland

E-mail:grazyna.wegrzyn@ue.wroc.pl

ORCID: 0000-0003-4735-2807 